\title{
Interactive comment on "Surface temperatures and their influence on the permafrost thermal regime in high Arctic rock walls on Svalbard" by Juditha Undine Schmidt et al.
}

\section{Anonymous Referee \#1}

Received and published: 5 January 2021

General comments:

This paper presents a four-year measurement series of near rock surface temperatures at coastal cliffs or canyon walls close to the Kongsfjord in the Ny Ålesund region, Svalbard and uses the well-known model CryoGrid 3 to calculate the energy balance at the observation sites and discusses the results. The authors show that the coastal sites are in general warmer than the sites a little bit further away from the fjord. This paper is carefully elaborated and shows interesting data and model results, which is an important contribution to a better understanding of the surface energy balance and related heat fluxes at a place where until now not many studies have been carried out 
in steep cliffs closely situated to a fjord. In general, before publishing this valuable article some major changes should be considered, which are outlined below:

Line 167, Neglecting influence of snow:

It is somehow understandable that the influence of snow is neglected for the investigated sites as the cliffs are steep and the influence of snow seems according to the authors until now not to be very important. However, there are two important points, which the authors do not consider enough in their paper, although they discuss the influence of snow in the paragraph of the discussing section on line 421 but this discussion cannot be used to justify their main approach of neglecting snow completely in their model approach.

- Firstly, recent studies show clearly that even in steep rock walls, small or even larger amounts of snow can accumulate on rock ledges and influence rock wall temperatures and change heat fluxes considerable (e.g.: Haberkorn et al. 2015, 2016 and 2017) and their logger RW01 and their comment in the caption of table 5 shows that snow seems already today have some influence at certain cliff sites!

- Secondly, performing climate scenarios coupled to model runs of CryoGrid 3 not taking into account snow for future conditions is not at all reasonable as in the future probably snow cover is may going to increase considerable during winter time particularly at sites which are close to a large moisture source (North Atlantic Ocean).

Therefore, I suggest to a) include in CryoGrid 3 a scenario including snow, which should not be a big problem as CryoGrid 3 is already well prepared and b) omit the future scenario runs in this paper (mainly chapter 4.5 and 5.4 ), as this part does not add any important additional information or only results, which are extremely speculative as the authors admit by themselves on line 474. Particularly as the authors cannot really convincingly show and explain that snow is not going to play an important role in the future. However, a future snow cover at the small cliff sites can strongly change the whole thermal regime (e.g. the canyon site could be filled by more snow and

Printer-friendly version

Discussion paper

\section{2}


corresponding snow drift by wind in the future).

Line 121, assumption neutral atmospheric stratification:

It is understandable that the authors try to simplify the very complex processes of the turbulent fluxes. However, assuming that the conditions at the cliff walls could be approached by using for all cases neutral atmospheric stratification is not justified. This assumption would mean that an air parcel moving close to the cliff would always have the same temperature (and density) as the surroundings at this position. This seems to be justified only for certain conditions during the year. The authors also justify in the discussion section their approach by tuning the roughness length until the model fits the observed values. This is reasonable to do. However, their estimated roughness length is, at least after my knowledge of such values and having seen the pictures of the measurement sites in the paper, at least one order of magnitude smaller what should be probably taken as roughness length for these specific observation sites.

Line 107, table 1 setting of surface temperature loggers:

The temperature loggers are located all at expositions of NE (except two of them ENE and $\mathrm{N}$ ). It would be interesting to see the influence of the different expositions, which could be easily modelled by CryoGrid 3 . I would assume that at this latitude the expositions do not play a very important role but it would be an interesting questions which could be answered by CryoGrid 3 .

Line 477, coastal cliffs in the high Arctic - a future geohazard:

This chapter does not add any important new information to the main topic of the paper. Please delete this section.

Specific comments:

Printer-friendly version

1. Line 31: better use: warming of atmosphere than warming of climate. The atmosphere can warm but the climate can only change but not warm. 
2. Line 46: may add the new literature from Etzelmüller et al. 2020; Etzelmuller, B., Guglielmin, M., Hauck, C., Hilbich, C., Hoelzle, M., Isaksen, K., Noetzli, J., Oliva, M., Ramos, M. (2020) Twenty years of European Mountain Permafrost Dynamics - the PACE Legacy. Environmental Research Letters 15, 14.

3. Line 50: May add some more literature here such as: Gisnås, K., Westermann, S., Schuler, T.V., Melvold, K., Etzelmüller, B. (2016) Small-scale variation of snow in a regional permafrost model. The Cryosphere 10, 1201-1215. Gisnås, K., Westermann, S., Schuler, T.V., Litherland, T., Isaksen, K., Boike, J., Etzelmüller, B. (2014) A statistical approach to represent small-scale variability of permafrost temperatures due to snow cover. The Cryosphere 8, 2063-2074. Haberkorn, A., Wever, N., Hoelzle, M., Phillips, M., Kenner, R., Bavay, M., Lehning, M. (2017) Distributed snow and rock temperature modelling in steep rock walls using Alpine3D. The Cryosphere 11, 585-607.

4. Line 51: Exposition is not only important for steep rock walls. It is in general important also for less inclined slopes particularly at lower latitudes; already much older literature has shown this.

5. Line 82: please give a value for the altered net short-wave radiation through the decrease in reflection so that a comparison to the value given for the change in downward long-wave radiation can be done.

6. Line 88: Is there no mean annual precipitation available in Ny-Ålesund after 2000 ?

7. Line 101: Please give some information about temperature logger calibration.

8. Line 104: the expression 'non-coastal rock walls' seems not very adequate chosen as this canyon cliffs are only about $600 \mathrm{~m}$ from the coast. In my view a 'non-coastal rock wall' would be several kilometers away from the fjord. Please change the wording.

9. Line 114/115: how is the latent heat effect considered. Please explain or give at least a reference where the reader could get more information.

Discussion paper

10. Line 176/177: please give a source for this volumetric ice and mineral content 
percentages.

11. Line 185, table 2: please give information about the source of your values you show in table 2. You could add a column in the table and show the references.

12. Line 194/195: Is the effect (transition between fjord and land) you describe here really resolved? I can hardly believe this!

13. Line 203: why do you use the radiation data from AROME-Arctic dataset when you have much better data from the BSRN stations. Please clarify?

14. Line 240, table 4: RW01 is modeled according to table 4, but it is shown that this site is covered by snow in figure 3. Therefore, it is mandatory to include snow in the model scenarios for this logger otherwise you contradict yourself in the paper (see also the general comments about snow).

15. Line 255, table 5: your model does not include snow but you wrote that only one logger is snow covered RW01 (figure 3). Please clarify this as it is very important for your assumption that there is no snow cover at the sites.

16. Line 275 , figure 4 : why is the variability (daily values?) not higher in comparison to figure 3 where there is much more variability in the same data. please clarify.

17. Line 335, figure 7: What is Fub in the figures? Is this not $G$ as noted in the figure caption?

\section{Literature:}

Haberkorn, A., Wever, N., Hoelzle, M., Phillips, M., Kenner, R., Bavay, M., Lehning, M. (2017) Distributed snow and rock temperature modelling in steep rock walls using Alpine3D. The Cryosphere 11, 585-607. Haberkorn, A., Phillips, M., Kenner, R., Rhyner, H., Bavay, M., Galos, S.P., Hoelzle, M. (2016) Thermal regime of rock and its relation to snow cover in steep alpine rock walls: gemsstock, central swiss alps. Geografiska Annaler: Series A, Physical Geography 97, 579-597. Haberkorn, A., Hoelzle,

Printer-friendly version

Discussion paper 
M., Phillips, M., Kenner, R. (2015) Snow as a driving factor of rock surface temperatures in steep rough rock walls. Cold Regions Science and Technology 118, 64-75.

Interactive comment on The Cryosphere Discuss., https://doi.org/10.5194/tc-2020-340, 2020. 